\title{
Teodora Krajewska, Official Female Doctor of Tuzla and Sarajevo: Medical Practitioner, Woman of Science, Polish Patriot and Feminist
}

\author{
Brigitte Fuchs ${ }^{1}$, Husref Tahirović ${ }^{2}$ \\ ${ }^{1}$ Department of Cultural and Social Anthropology \\ at the University of Vienna, Vienna, Austria, \\ ${ }^{2}$ Department of Medical Sciences of the Academy \\ of Sciences and Arts of Bosnia and Herzegovina, \\ Sarajevo, Bosnia and Herzegovina \\ Correspondence: \\ fuchsb196@gmail.com \\ Tel.: + 436506405150 \\ Fax.: + 431427749533
}

Received: 30 November 2019; Accepted: 30 December 2019

\begin{abstract}
A biographical note on Teodora Krajewska (18541935) reveals the details of her life and professional activities as an Austro-Hungarian and Yugoslav health officer (Amtsärztin) in Tuzla (1893-1899) and in Sarajevo (1899-1923). Teodora Krajewska, née Kosmowska was the third of nine official female doctors employed by the Austro-Hungarian administration in occupied Bosnia and Herzegovina (BH: 1878-1918) and charged with the special task of popularising public health and hygiene, particularly among Muslim women. A Polish intellectual and fervent patriot from Warsaw, Krajewska had left Congress Poland as a young widow in 1883 to study medicine in Geneva, Switzerland. In 1890, she became the first woman in Europe to be employed as an assistant professor at the medical faculty of the University of Geneva but was forced to resign in 1892. In the same year, she was both awarded her doctorate and appointed to the position of an Austro-Hungarian female health officer in Tuzla. After being nationalised in Austria, she reported for duty in Tuzla in March 1893. In 1899, she accepted her transfer to a newly created position in Sarajevo where
\end{abstract}

she was active as an official physician until 1922/23. She contributed to contemporary medical science through her research on leprosy and osteomalacia in Bosnia. She returned to Warsaw in 1928 and devoted herself to the translation of Serbo-Croatian literature and writing her memoirs on her life and activities in $\mathrm{BH}$.

Key Words: Teodora Krajewska - Female Health Officer - Bosnia and Herzegovina 1878-1918 - Tuzla - Sarajevo.

\section{Introduction}

After Austro-Hungarian (AH) troops occupied the Ottoman province of Bosnia and Herzegovina $(\mathrm{BH})$, the local populations immediately became the target of an AustroHungarian civilising mission, which primarily involved the implementation of a general system of public health and hygiene and a structure of general education. In 1890, an Austro-Hungarian medical commission charged with surveying the health of BH's population recommended the government commit female health officers to the occupied territory. Their goal would be to combat epidemic and endemic diseases, particularly (endemic) syphilis, among the female Muslim population without antagonising the Muslim elite of the country. Though female physicians were not accredited in Austria, $\mathrm{BH}$ 's governor, the Minister of Finance Benjamin de Kállay, approved of this suggestion and concerned himself personally with the 
creation of positions for female health officers in the districts of Tuzla (1891) and Mostar (1892). The Austro-Hungarian administration, however, only hesitantly effectuated the plan of employing female health officers in all districts, creating further positions in Sarajevo and Banjaluka in 1899, in Travnik in 1902, and in Bihać as late as 1908.

The choice of Tuzla as the first residence of an official female doctor seems to have been related to the head of the district, Antun Vuković von Vučijidol, exhibiting a thoroughly positive attitude towards female physicians (1). The first Austro-Hungarian official female doctor in Tuzla, Anna Bayerová, however, had complained upon her arrival in 1891 that she had been equipped with neither an office, clinic or residence, nor with the (free) medication she was expected to distribute among her patients. She abandoned her office in Tuzla after three months of conflict with the local administration and resigned her service after an authorised transfer to Sarajevo where she was not permitted to practice her function. ${ }^{1}$

In 1892, the position of female doctor in Tuzla was again advertised by the administration and, in $1892 / 1893$, filled by Teodora Krajewska whose life, professional work in Tuzla and Sarajevo, and research activities constitute the primary concern of this paper.

\section{Teodora Krajewska's Biography}

Teodora (Theodora) Kosmowskich Krajewska is among the best-known female physicians of her time. Contemporarily, many features and portraits in newspapers and journals that concerned both her person and professional work were published in German (2-8), French (9) and Polish (10). In Poland, she is known as a Polish intellectual and female pioneer of medicine (11-13).

\footnotetext{
${ }^{1}$ See Dr. Anna Bayerová: The First Official Female Doctor in Bosnia and Herzegovina. AMA. 2019;48(1): 121-6.
}

Her authoritative biography, written by her nephew, Zbigniew Danielák, is included in the Polski Słownik Biograficzny (Polish Biographical Dictionary) (14), and she is also mentioned as a female pioneer of medicine in Laura Lynn Windsor's international Encyclopedia (15). She is also included in numerous collective biographies of Polish female intellectuals and physicians (16-17), and in Ctibor Nečas' monograph on the AustroHungarian female health officers in $\mathrm{BH}$ (18). She is mentioned frequently in writings on both the health-care system in $\mathrm{BH}$ at the time of the Austro-Hungarian occupation (19-26) and on the local Polish communities (27). She has also been featured by several writers $(28,29)$ and chroniclers $(30)$ in $\mathrm{BH}$.

Krajewska left an autobiographical "Diary" (Pamietnik) which, in fact, she had written during her retirement in Warsaw. It predominantly contains memoirs of her medical practice in Bosnia and impressions of her childhood and youth in Warsaw under Russian rule (1). Pamietnik was first edited in 1989 by the Polish historian and archivist Boguslawa Czajecka (1938-2003) who prefaced Krajewska's memoirs with a biography (12). Krajewska's memoirs reveal the deep imprint that the suppression of the Polish language in Congress Poland had left on her intellectual formation as a pupil and young woman. She remained deeply dedicated to the national cause of Poland throughout her life and sought to actively support and promote Polish compatriots and communities whenever she could and wherever she went.

Teodora Krajewska (Picture 1) was born as one of eight daughters to Ignacy Kosmowski and his wife Seweryna Glówczynski in Warsaw in $1854^{2}$. She attended the II. girls' gymnasium in Warsaw, passing her schoolleaving exam in 1872 'with honours' (14).

\footnotetext{
${ }^{2}$ Nečas (1992: 71) gives September 5, 1854 as the exact date of her birth; this date is quite probably confusing the dates of birth (unknown) and death (September $5,1935)$.
} 
Her father, a civil servant of the communal educational administration in Warsaw, was a supporter of the idea of women's education and of their participation in nation building. Feminism, however, was debated controversially among the Western-oriented Polish intellectuals who, as with Krajewska's family, largely shared a social background derived from the Polish Szlachta nobility. In 1874, Teodora qualified as a mathematics teacher and began to conduct lessons in her former school. In 1876, she married Antonín Krajewski, a philology teacher in a Warsaw boys' gymnasium, who had participated in the anti-Russian January Uprising in 1863/64 (14). The couple formed the centre of a patriotic intellectual circle until the premature death of her husband in 1880. As a young widow, Krajewska started again to work as a teacher in a private school operated by her aunts Leokadia and Bronislawa Kosmowski. Her personal interests had shifted to the study of literature and she was able to publish her first literary efforts in a Warsaw newspaper in 1882 (14).

At that point, however, she had made up her plan to take up academic studies in Switzerland, though her family expected her to remarry (13). She reports that she had first considered studying philology, but her parents had convinced her to choose medicine (31). In 1883, she headed for Geneva without obtaining the financial resources which would have enabled her to survive permanently without gainful activities. At first, she enrolled at the Natural Sciences Faculty of Geneva University, becoming also one of the most active members and later the president of the Geneva based 'Société des étudiants polonais' (32).

She was awarded a Bachelor of the Natural Sciences degree in 1885, immediately thereafter enrolling at the university's medical faculty. Troubled by financial circumstances, she accepted her Polish friends' help in procuring her a grant to continue her

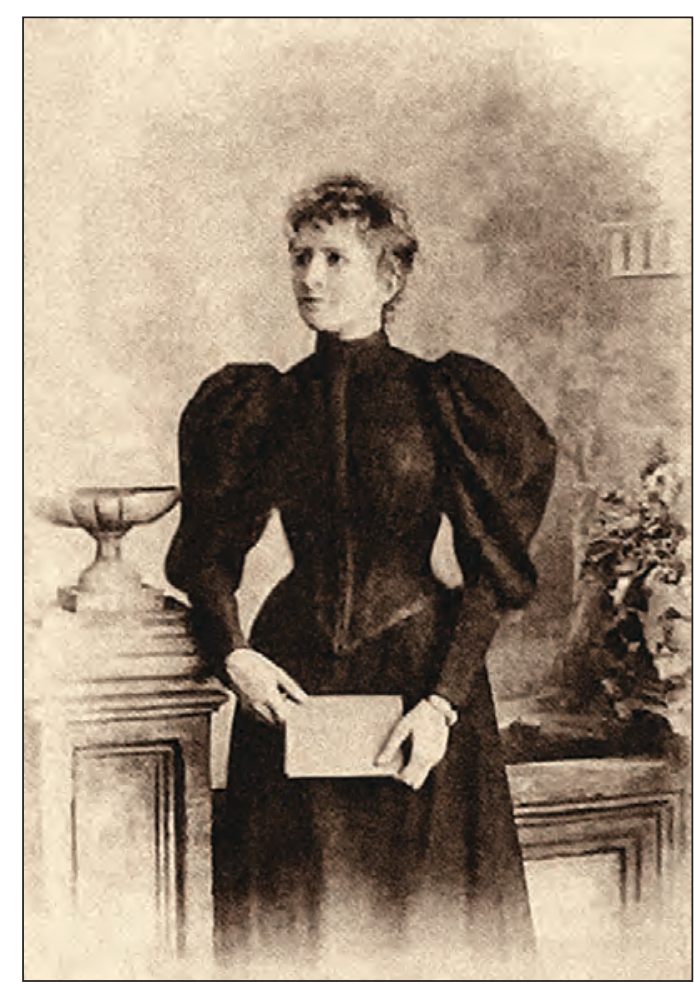

Picture 1. Dr. Teodora Krajewska, née Kosmowska (1893). Source: Mackiewicz, Joanna. Pierwsze kobiety z dyplomem lekarza na terenie zaborów rosyjskiego i austriackiego. Medycyna Nowożytna. Studia nad Kulturq Medyczną. 1999;6(2):82. Original caption: Fot. 2. Dr Teodora z Kosmovskich Krajewska. Fot. w pracowni M. Schultheisa w Tulli ok. 1893 r. (ze zbiorów rodzinnych).

medical studies. While still studying, Moritz Schiff ${ }^{3}$, professor of physiology at Geneva University, appointed Krajewska as his assistant in 1890 and, later, as head of his laboratory (14). Krajewska was therefore the first woman to ever be appointed an 'assistant professor' and soon became confronted by the animosity of male colleagues who were not ready to accept women in academic positions. Due to the pressure they exerted, she reluctantly resigned in 1892. In the same year, she was awarded her medical doctor's de-

\footnotetext{
${ }^{3}$ Moritz Schiff (1823-1896) is a physiologist who contributed substantially to the study of the circulatory system and the action of the vagus nerve. Contemporarily, he was notorious rather than famous, as he relied on vivisection.
} 
gree; her thesis 'Recherches physiologiques sur la reaction de dégénerescence' being awarded a first prize by Geneva University (14). In need of an income, Krajewska could not consider practising in Warsaw, because the administration of Congress Poland did not recognise foreign diplomas (1). As she reports, a Polish friend informed her of the Austro-Hungarian call for applications from fluent 'Slavic-' and German-speakers for two positions for female health officers in occupied $\mathrm{BH}$. Her application proved a success due to the interventions of Polish friends on her behalf (1), and she was appointed as a female health officer of Tuzla on November 28,1892 . Before she could report for duty in Tuzla, she had to travel to Vienna where she learned that her nationalisation and the recognition of her Swiss diploma ${ }^{4}$ would take 'a couple of months' (1). She therefore passed her time in Vienna taking lessons in Bosnian and attending lectures as a guest at the Medical Faculty of Vienna University.

As a new Austrian and female physician, she immediately offered her support to the Austrian 'Association of Women's Advanced Education' (Verein für erweiterte Frauenbildung) and advocated Austrian women's right to academic studies in the Cracow daily newspaper Nowa Reforma. In 1894, she was a member of a delegation of Austrian women to the Minister for Cultus and Education (14). Against this background, Krajewska became the most frequently featured Bosnian female physician in the Austrian and German women's press. In Tuzla, the governor's wife, Vilma de Kalláy, née Bethlén visited her and published a report on her work among Muslim women in 1899 (6).

\footnotetext{
${ }^{4}$ Danielák (1970: 102) remarks correctly that she was the first Austrian female physician because her Swiss diploma was recognized in Austria, while the Austrian authorities continued to refuse the 'nostrification' of the Swiss diplomas of both Czech domestic official physicians in $\mathrm{BH}$, Anna Bayerová and Bohuslava Kecková.
}

Krajewska arrived in Tuzla on March 20, 1893 and was sworn into office nine days later. In the context of the creation of new positions for female health officers in 1899 , she was invited to continue her work in Sarajevo. She accepted the transfer due to the chance to join the local Polish community, remarking in her memoirs repeatedly how much she had missed the company of Polish compatriots in Tuzla. Though her workload in Sarajevo was substantial, she immediately began her tireless activity for the Polish $\mathrm{Club}^{5}$; she gave Polish lessons to the children of the members of Sarajevo's Polish community, organised events and lectures, and collected donations at the outset of the Polish Revolution of 1905 (14).

Her social activities, however, were at no point restricted to Poland; she gave lessons in reading and writing to a young Muslim woman in Tuzla until said woman ran off to marry (1); she organised a collection of donations for the inhabitants of Travnik after the city had burnt down in 1903 (1), and she struggled for equal pay for the AustroHungarian female health officers, who were discriminated against considerably vis-à-vis their male colleagues (18).

She always remained in close contact with her numerous relatives and used her annual six-week leave to visit her sisters and friends in Poland. She also took repeated leaves to participate in medical and feminist conferences such as a gynaecologists' conference in Geneva in 1896, an international women's conference in Berlin, and an international medical congress in Budapest in 1909 in which she presented her research on endemic osteomalacia in Bosnia. After World War I, she hoped to return to Poland but the lack of an adequate employment op-

\footnotetext{
${ }^{5}$ For the historical background of Polish exiles who had left partitioned Poland and founded so-called 'colonies' elsewhere, e.g. in Bosnia, see Tomasz Jacek Lis, Polskie osadnictwo i duchowieństwo w Bośni i Hercegowinie od 1894 do 1920 roku, Toruń 2014.
} 


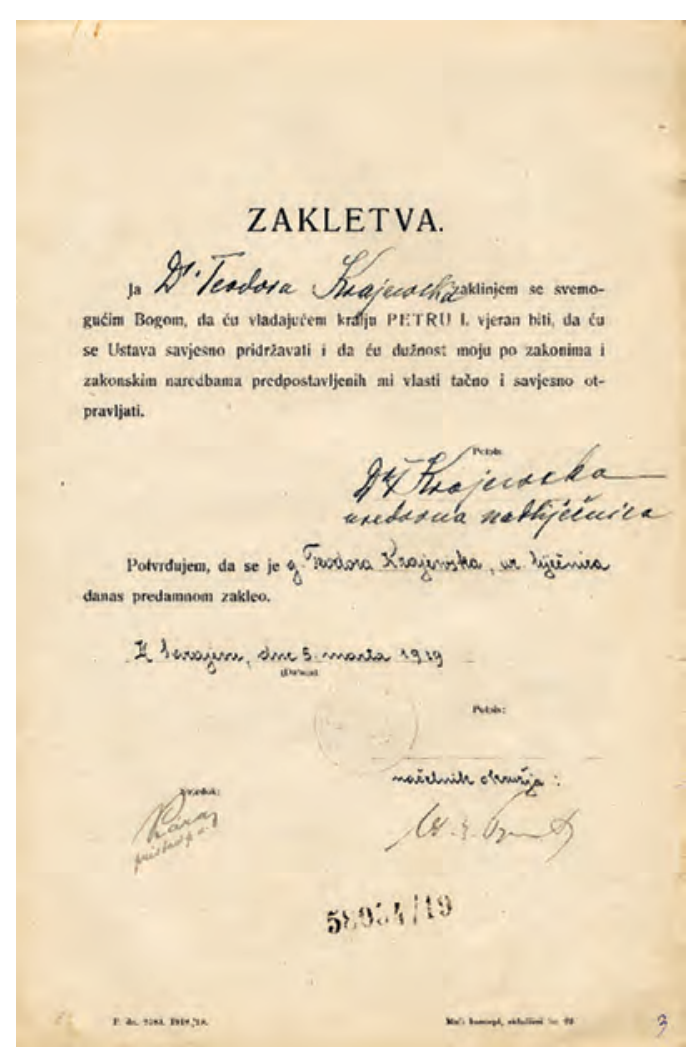

Picture 2. Dr. Teodora z Kosmovskich Krajewska's oath of allegiance to King Peter I that she will abide by the constitution und exercise her duty according to the laws and regulation of the Yugoslavian authorities.

portunity in Warsaw prompted her to stay in $\mathrm{BH}$. She took the oath of office to the Kingdom of Yugoslavia on March 5, 1919 (Picture 2).

At that point, however, her sight had already deteriorated to a point that she decided to have a cataract operation in Prague. When the operation failed, she was forced to retire in 1922. Since her pension did not suffice and she had no savings she continued working as a physician in a tuberculosis clinic in Sarajevo until 1925 (12). In 1928, she finally returned to her beloved hometown, Warsaw, in the Second Polish Republic she had longed for. She, however, did not 'feel at home anymore' and her family had left for Southern Poland during the time she had been active in $\mathrm{BH}$ (13). She missed

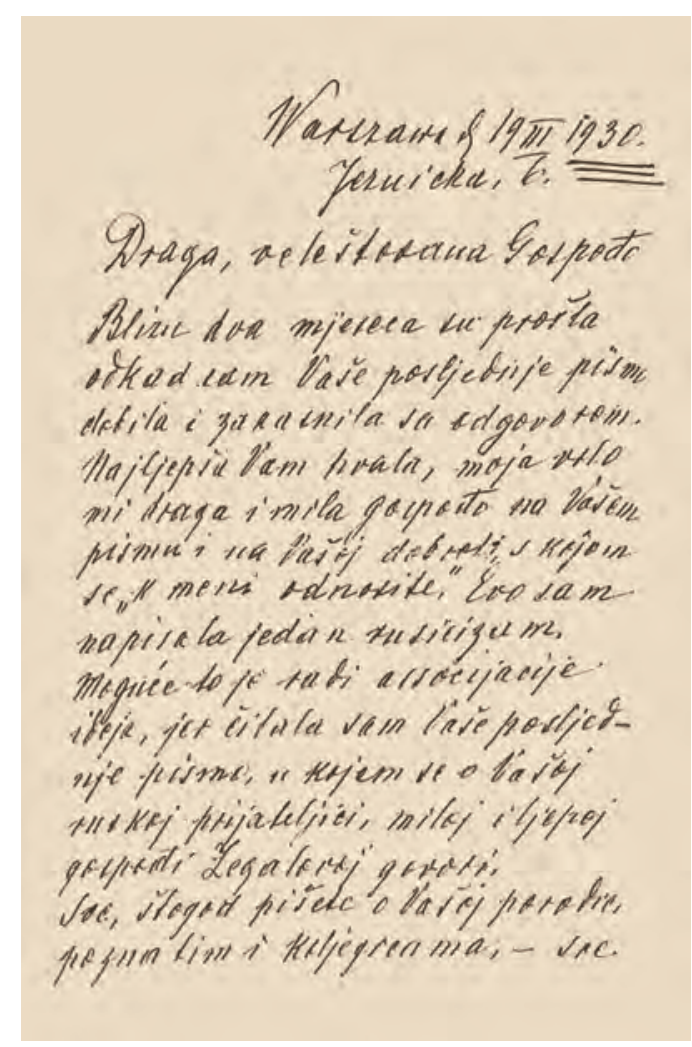

Picture 3. First page of a letter by Teodora Krajewska addressed to Mrs. Milica Popovic in Sarajevo dated March 19, 1930.

Bosnia and the friends she had had to leave back there greatly and expressed her nostalgia for Bosnia in a letter to Milica Popović in Sarajevo in the spring of 1930, remarking, 'I have become deeply committed to Bosnia, country and people' (Picture 3). ${ }^{6}$ She started to translate Serbo-Croatian literature and published Verka Škurla-Ilijičss (1891-1971) novel Hanumica (1928) in the Polish weekly women's newspaper 'Bluszcz' as a special supplement.' She dedicated her last years to writing her unfinished memoirs and died on September 5, 1935 in her home in Warsaw.

\footnotetext{
${ }^{6}$ Letter by Teodora Krajewska addressed to Mrs. Milica Popovic in Sarajevo dated 19 March 1930 (Archives of Husref Tahirović).

${ }^{7}$ The novel also became published as a book, see Werka Szkurla Ilijicz; Hanumica, przeł. T. Krajewska, Warszawa: Towarszystwo Wysanwnicze 'Bluszcz', ca. 1928.
} 


\section{Krajewska's Professional Activities in Tuzla, 1893-1899}

In March 1893, Krajewska finally arrived in Tuzla and introduced herself immediately to her superiors who informed her about the country and people. She was sworn into office on March 29, 1893, her status becoming permanent on September 11, 1895 (33). As compared to her Czech predecessor Anna Bayerová who had pursued the aim of being a 'female doctors for all women', Krajewska adhered to the Austro-Hungarian guidelines in caring predominantly for Muslim women and children In 1893, when she started to practice, she treated 553 patients, $36.5 \%$ of whom were Muslims. However, the share of Muslim patients in relation to other patients was to steadily rise from that point. In 1898 she treated 607 patients, the Muslim share equalling 69\% (34). Her statistics account for the treatment of 4,739 patients from March 1893 to July 31, 1899, most of whom were women and children. Nevertheless, she also treated 193 men (4\%), her statistics comparatively exhibiting the highest share of adult males who had themselves treated by a female doctor (34).

From Krajewska's memoirs, it can be concluded that there was no urgent need to persuade (Muslim) women in Tuzla of the benefits of utilising public health. However, even the patients who at first were predominantly Christians consulted her in her surgery or sent for her, revealing that the policy of being treated free of charge by a female doctor introduced in 1891 had been widely accepted by 1893 . She was also tasked with creating a maternity ward in the community hospital (Gemeindespital) established by the Austro-Hungarian military administration in 1879 . Rehoused in 1886 , the hospital with 30 beds and an external clinic was declared a civil public hospital in 1894 (34). Nevertheless, despite these extra responsibilities, Krajewska still continued to dutifully visit Mus- lim families in their homes to teach Muslim women hygiene and to collect data on their living conditions. She fought against unhygienic habits such as all household members, guests and passing foreigners sharing the water pitcher (ibrik), towels or cutlery, and the widespread avoidance of ventilating living rooms or taking baths (35). In order to explain to people that they and their children might catch infectious diseases such as 'frenjak' (endemic syphilis, 'frenga'), she was also ordered to other localities of the Tuzla district (35). In 1894, the authorities assigned her to participate in combating a cholera epidemic that had spread along the railway line from Hungary via Croatia to $\mathrm{BH}$.

In the annual reports on her professional activities, she criticised, in unison with Kecková in Mostar, the common diet in $\mathrm{BH}$, consisting predominantly of cornmeal, 'fat meat' and 'fat milk', the excessive consumption of coffee and tobacco and the inadequate diet administered to infants and toddlers (35). However, in contrast to her Czech colleague, Krajewska did not exhibit a significant amount of sympathy for her clientele. As many Austro-Hungarians did, she disliked the existence of Slavic Muslims, and depicts poor rural Muslims repeatedly as 'beyond description' in her memoirs (1). Her dislike is particularly expressed in the way she was disgusted by the local population dressing in 'oriental' attire which she judged to be 'unhealthy' and 'ugly' (1). Moreover, she complained vehemently about the inability and/or unwillingness of her mostly poor, illiterate clients to follow her advice, considering them a class of people lacking 'intelligence' (36). On the other hand, she remarked that she much preferred to talk to members of the Muslim elite, because they were 'progressive' and 'rational'.

At an 1896 international feminist congress in Berlin, Krajewska expressed her conviction that the Austro-Hungarian Empire (AHE) had to import civilisation and 
progress' to $\mathrm{BH}$, and Bosnian women must be educated regarding hygiene 'from above' (37). While her memoirs demonstrate that she never lost her distinct class consciousness and Orientalist attitudes, they also reveal that Krajewska became thoroughly disenchanted with Austria-Hungary's policy of 'civilising' BH by 1908 . At that point, she remarked that the civil officers coming to $\mathrm{BH}$ were, in fact, being abused by the AH authorities by contributing to a politically dubious project for little money (1). She remembered her time in Tuzla as a time of never-ending work, self-doubt, and feelings of loneliness and depression (1). When she first travelled to Sarajevo in 1898, she reports having been enthusiastic about its beauty, its urban character, its new hospital, and the presence of a Polish Club (1). Therefore, she accepted the offer to be transferred to the 1899-created position of an $\mathrm{AH}$ female health officer in Sarajevo without much hesitation.

\section{Krajewska's Professional Activities in Sarajevo, 1899-1923}

Krajweska was appointed the female health officer of Sarajevo on May 23, 1899 (33). After her transfer in the summer of the same year, she started to function as an official physician in Sarajevo on October 1, 1899 (34). In 1900, Krajewska - as with Bohuslava Kecková in Mostar - was appointed a school physician at the higher girls' school in Sarajevo where she gave hygiene lessons to fifth-grade students. She also taught hygiene at the Institute for Teacher Education and, later, at the local private Roman Catholic and Islamic girls' schools (18). As in Tuzla, her field of duties covered conducting clinics at the outpatient ward in the provincial hospital (Landeskrankenhaus) in Sarajevo where she was also involved in establishing a maternity department. She was charged with 'approaching' and visiting Muslim women in their home in order to advertise hygiene and public health utilisation. She reported on the health and living conditions of the Muslim population in Sarajevo where she exhibited content illustrating that not only upper-class, but also middle-class Muslims had repudiated tradition $(1,36)$. Her memoirs contain the observation that affluent Muslim women, in fact, consulted male physicians, though in the company of a male relative who communicated with the doctor, a man who was not expected to administer any physical examinations (1). Her complaints on the 'dirt' and lack of hygiene and fresh air in the houses of poor urban and particularly rural Muslims resemble her reports on the living conditions in both Tuzla and the Tuzla district $(35,36)$. Her disinclination to touch poor rural women is made clear in her memoirs, in which she remarks that she had suggested the authorities assemble rural clients outdoors rather than in buildings, quite obviously because she suffered repeatedly from panic attacks when she was confronted with what she dubbed rural women's 'evaporations' (1).

In 1899, she treated no more than 128 patients in Sarajevo from October to December because the $\mathrm{AH}$ administration had ordered her to combat a smallpox epidemic, the focus of which was considered Derventa, immediately upon her starting work. She was responsible for the vaccination campaign in the districts of Sarajevo and Travnik from 1900 to 1902 . In the first half of 1902, she vaccinated 2,912 people in Sarajevo and its rural surroundings (18). From 1902 , she was assigned to visit the rural regions of the district in order to examine the village women for endemic syphilis. When she visited the mountainous quarters of Sarajevo or rural villages, she rode a Bosnian horse in the warm seasons but had to travel by foot or carriage during the winter (1). From 1900, she treated far more than 1,000 patients every year, more than two thirds of whom were Muslim women and children 
(34). When she decided to return to Poland in 1928, the city council awarded her a prize for her many years of work as an official doctor in Sarajevo (13). Back home in Warsaw, however, she expressed her deep regret to have left Bosnia in a letter to Zdenka Marković ${ }^{8}$ in Zagreb: 'My work bound me to Bosnia and filled me with the enthusiasm without which I cannot live.'

\section{Krajewska's Research and Publishing Activities}

Krajewska was the first female physician in the AHE, and probably in Europe, to publish in a medical journal and participate in medical congresses. Her memoirs clearly demonstrate that she would have much preferred to keep her research position at Geneva University if she had had the choice (1). One of the research activities she pursued in $\mathrm{BH}$ was volunteering to document the cases of leprosy in the Tuzla district. Leprosy was considered of particular interest by the $\mathrm{AH}$ authorities due to fact that the Vienna School of Medicine had advanced the theory that syphilis was a transformative form of leprosy and had not been introduced as a new disease from the Americas in the 1500s, as a hegemonic French theory suggested (38). In April 1898, she received a commendation for her leprosy research (33) which, however, was not published under her name. The focus of her own research was the discovery that osteomalacia was widespread in the districts of Tuzla and Sarajevo $(35,36,39,40)$. Osteomalacia had been identified correctly as 'adult rickets' by Francis Glisson's (1597?1677 ) in the $17^{\text {th }}$ century but became confused with osteoporosis as a form of malacia in the $19^{\text {th }}$ century, when the disease's description as a female disorder probably related to the ovaries became intensely debated.

8 Zdenka Marković, Croatian writer and translator (Pozega, 10 January 1884 - Zagreb, 14 October 1974).
At that point, malacia meant the advanced demineralisation of the bones that forced the diseased to crawl on all fours or to stay in bed and was frequently accompanied by 'osteomalacic cachexia' (wasting syndrome), leading to death within 6 to 10 years. In Central Europe, around 1860, this advanced form of osteomalacia was called 'puerperal' and defined as a disorder of women of childbearing age whose condition did not remain restricted to severe pains in the costal and sacral regions as was observed in male cases. The disorder was depicted as being exacerbated by repeated pregnancies, births, and breastfeeding of infants, and was said to be accompanied by a progressive softening and deformation of the pelvis and bones in general, forensically visible in the severely deformed femurs, and a loss in body length of up to 20 centimetres or more (41). Advanced osteomalacia frequently resulted in a pelvis fracturing during childbirth and made delivery a deadly risk. The disease which was considered to occur 'rarely' and locally endemically became a vehicle to promote gynaecological surgery, from Caesarian sections to Porro operations and ovariectomies (42). However, the total number of regularly discussed single and endemic cases all over Europe between 1750 and 1900 did not exceed approximately 300 (42). Around 1900, however, the case descriptions multiplied in Austria, Hungary and particularly in $\mathrm{BH}$, where Krajewska and her colleagues, Gisela Januszewska, née Rosenfeld (Banjaluka), and Bohuslava Kecková (Mostar), were confronted with the most extensive osteomalacia 'endemics' ever observed.

Krajewska reports that, on her first official trip to Zvornik, Srebrenica and Vlasenica as a female health officer, she found no less than 22 cases of osteomalacia in some mountainous rural localities and gorges. She states that male $\mathrm{AH}$ doctors would not have discovered them because they were not allowed to see Muslim women, who were 
captive in their homes $(1,35)$ In 1900, Krajewska provided in 'Wiener Medizinische Wochenschrift' a case description concerning 50 occurrences of osteomalacia in the district of Tuzla (39). In 1909, she reported, at the Medical Congress in Budapest, 150 cases of osteomalacia in Sarajevo and its surrounding district, 116 of which she considered 'puerperal' $(40,36)$. She had found the advanced cases to occur particularly on the slopes of Mount Trebević, in the 'hills of Mahmutovac, Begovac and Berkusa, in Fojnica and in Rudo (40). She stated both in 1900 and 1909 that only Muslim women suffered from osteomalacia, though in 1901 the disease was described as also being endemic in neighbouring Croatia (43). Drawing heavily on Orientalist stereotyping, Krajewska mentioned the causes of osteomalacia as being, in addition to the 'damp climate,' 'lack of sun,' poverty, and malnutrition, 'Muslim customs' such as early marriage, veiling, extended lactation periods, and too much time indoors $(35,36,39,40)$. In 1909, she examined the hypothesis of a correlation between osteomalacia and the involuntary contraction of muscles (tetany) as another affliction occurring among poor women, predominantly in the cold season. Since tetany is, in fact, commonly caused by a deficiency of calcium, Krajewska was able to verify the thesis (40).

Following Austrian medical doctrine, Krajewska rejected the hypothesis that osteomalacia was an effect of a 'malfunction of the ovaries'. However, deviating from this doctrine, she viewed, 'gravidity' and 'other functions of the sexual sphere (sexual intercourse, menstruation, lactation)' as causes of osteomalacia (39). As suggested by French and Austrian doctrines, she administered phosphorus in cod liver oil, stating that this medication was much requested even by women she saw for the first time (40). Her assumption of the exacerbation of osteomalacic suffering by the excessive sex- ual demands of Muslim husbands was new and quite probably inspired by contemporary feminist discourse. Obviously, Krajewska drew on a pro-birth control discourse that claimed that 'hypersexual' husbands were morally responsible for the exhaustion and early death of women who had to bear numerous children (44). Marrying this to bone disease, her report on osteomalacia in Bosnia can be read as a plea for birth control, contemporaneously advocated by Neo-Malthusians, feminists, and eugenicists (45). Regarding the then controversial debate concerning osteomalacia, Krajewska's contribution, might be considered substantial, however. Based on the unprecedented number of 200 cases, she had been able to demonstrate that the softening of bones was obviously a metabolic disorder caused predominantly by malnutrition and a lack of sunlight.9 The latter fact became to be accepted only 10 years later, when an osteomalacia 'endemic' occurred in Vienna after World War I (42). While Krajewska's work was much quoted and highly respected in Bosnia, she felt, as Tomasz Lis states (13), ignored by the international scientific community due to her gender.

\section{Concluding Remarks}

Teodora Krajewska, née Kosmowska, a young widowed Polish intellectual from Warsaw, made the unusual decision in 1882 not to remarry but to take up academic studies in Switzerland. She studied Natural Sciences and Medicine at the University of Geneva successfully, and was appointed an assistant to Moritz Schiff in 1890. From her memoirs, it can be concluded that she appreciated her research work and hoped to be promoted as the head of Schiff's laboratory.

\footnotetext{
${ }^{9}$ However, Gisela Januszewska (official female physician in Banjaluka) cared for a locally even higher number of osteomalacia patients and came to the same conclusion (46).
} 
However, she became bullied by her male colleagues, who did not tolerate a woman in an academic position. Lacking means, Polish friends succeeded in placing her into the position of an $\mathrm{AH}$ female health officer in Tuzla (1892-1899) who was transferred to Sarajevo (1899-1923). While she performed her numerous duties in an exemplary manner and did not voice her bias against (poor and rural) Muslims in public, she privately expressed her antipathy to her clients due to the Social Darwinist and eugenicist attitude she had quite probably adopted as a natural scientist and feminist of her time $(47,48)$. Despite her substantial workload, she pursued research on ('puerperal') osteomalacia as a disorder widespread locally in $\mathrm{BH}$. Her research, however, did not bring her any laurels internationally, her memoirs revealing her permanent frustration concerning discrimination against 'intelligent' women as professionals (1). Krajewska who lived and worked for 35 years in $\mathrm{BH}$ was, however, highly respected as an official doctor and medical practitioner in the districts of Tuzla and Sarajevo. Additionally, at the fin-de-siècle, she was the first female medical scientist in $\mathrm{BH}$ and in the AHE.

Authors' Contributions: Conception and design: BF and HT; Acquisition, analysis and interpretation of data: BF and HT; Drafting the article: BF and HT; Revising it critically for important intellectual content: $\mathrm{BF}$ and HT; Approved final version of the manuscript: $\mathrm{HT}$ and BF.

Conflict of Interest: The authors declare that they have no conflict of interest.

\section{References}

1. Krajewska Teodora z Kosmowskich: Diary (prepared for print by Boguslawa Czajecka) [in Polish]. Cracow: Krajowa Agencja Wydawnicza; 1989.

2. Krajewska T. Letters from a Bosnian doctor [in German]. Wiener Frauen-Blatt. 1893; 17(206) and 20(207).

3. MD Theodora Krajewska [in German]. Deutsche Hausfrauen-Zeitung. 1897;24(15).
4. SR, i.e. Schoenflies R. Women's lives [in German] Der Bazaar. Illustrierte Damen-Zeitung (Berlin). 1897;43(22):FF267-8.

5. Kuhnow A. Practicing female doctors in the present [in German]. Illustrierte Zeitung (Leipzig/ Berlin). 1898;111(2872).

6. Kállay V. Female physicians in Bosnia [in German]. Frauen-Werke. 1899;6(3):4-6.

7. Brod B. A visit to MD Theodora Krajewska in Sarajevo [in German]. Dokumente der Frauen. 1901;5(8):260-4.

8. Dr. Theodora Krajewska, official female doctor in Sarajevo [in German]. Daheim. 1902;38(16):7.

9. Lipinska M. Female physicians [in French]. Revue Universelle.1901;51.

10. Baschkopf J. Experiences from the practise of a female doctor in Bosnia [in Polish]. Nowiny Lekarskie. 1905;17(1/9):57-61.

11. Nečas C. MD Teodora Krajewska. An official female doctor in Tuzla and Sarajevo [in Polish]. Archiwum Historii i Filozofii Medycyny. 1987;50(1):75-98.

12. Czajecka B. Biography [in Polish]. In: Krajewska, Teodora z Kosmowskich: Pamiętnik (przygotovata do druku Boguslawa Czajecka). Crakow: Krajowa Agencja Wydawnicza; 1989. p. 5-22.

13. Lis TJ. Teodora Krajewska - a Bosnian dr Quinn [in Polish]. [updated 2014 March 28; accessed 2019, Nov 9]. Available from: http://o-historii.pl/ teodora-krajewska-bosniacka-dr-quinn /.

14. Danielák Z. Krajewska z Kosmowskich Teodora (1854-1935) [in Polish]. Polski Slownik Biograficzny, vol. XV. Wroclaw: Zakład Narodowy Imienia Ossolińskich, Wydawnictwo Polskiej Akademii Nauk. 1970; p. 101-3.

15. Krajewska, Teodora (1854-1935). In: Windsor, Laura Lynn, editor. Women in Medicine. An Encyclopedia, Santa Barbara: Clio; 2002. p. 122.

16. Mackiewicz J. The first women with a MD diploma in Russia- and Austria-ruled Poland [in Polish]. Medycyna Nowozytna. Studia nad Kulturą Medyczną. 1999;6(2):79-98.

17. Bojczuk H. Female doctors in the Medical Society of Warsaw 1875-1939 (first part, 1875-1905) [in Polish]. Medycyna Nowozytna. 2008;15(1):139-57.

18. Nečas C. Among Muslim Women. The Female Health Officers in Bosnia and Herzegovina 18921918 [in Czech]. Brno: Masaryk-University; 1992.

19. Kállay V. To our women's world [in Bosnian]. Nada. 1895;1(10):188-9.

20. Weiss O, Preindlsberger J. Obstetrics - Gynaecological Division [in German]. In Jahrbuch Bosn.Herceg. Landesspitales in Sarajevo: Sarajevo: Landesdruckerei; 1903. p. 473-529. 
21. Jeremić R. Contributions to the History of Health and Medical Opportunities in Bosnia and Herzegovina under Turkey and Austria-Hungary [in Serbian]. Beograd: Naučna Knjiga; 1951.

22. Karahasanović A. Tuzla hospital and its first doctors [in Serbian]. Srp Arh Celok Lek. 1958;10:1-5.

23. Azabagić S. One hundred years of health service in Tuzla [in Bosnian]. Acta Med Sal. 1974;3(2):5-20.

24. Berić MB. The Importance and Role of Polish Physicians in the Development of Obstetrics and Gynecology in the Yugoslav Countries by 1918 [in Serbian]. Acta hist med stom pharm med vet. 1986;26(1-2):63-70.

25. Ibrahimagić OC, Zukić S, Čustović A. Health Care in Tuzla and Tuzla Area in the Second Half of the Nineteenth Century. Acta Med Sal. 2009, 38(1):1-5.

26. Alispahić N. Theodora Krajewska: First female doctor - gynecologist in Tuzla and Bosnia and Herzegovina [in Bosnian]. [S. 1. : s. n.]; 2016.

27. Lis TJ. Contribution of Poles to the modernization of Bosnia and Herzegovina during the Austro-Hungarian period (18781918) [in Polish]. In: Studia Migracyjne - Przeglad Polonijny. 2014;40(4, 154):10924. Available from: http://cejsh.icm.edu.pl/cejsh/ element/bwmeta1.element.desklight-62e203f63a23-417a-b3ac-921bd4609318?q=bwmeta 1 . element.desklight-6de933b2-c248-43a2-9b95001bb6f4fe6a;5\&qt=CHILDREN-STATELESS.

28. Alispahić N. A bow for Mrs. Krajewska [in Bosnian]. In: Leda Saliniana: Kulturna hronika Tuzle. Tuzla: Radio Kameleon; 1997. p. 424-26.

29. Markovit (Marković) Z. What we women have made to the Croatian-Polish rapprochement [in Croatian]. Marulić. 1976;9(4)323-38.

30. Trifković D. Polish women in Tuzla [in Bosnian] In: Trifković D, editor. Tuzlanski vremoplov III. Tuzla: Universal; 1988. p. 35-7.

31. Pioneers of women's academic education in Austria [in German]. In: Jahresbericht des Vereines für erweiterte Frauenbildung in Wien, vol. VIII, Oct. 1895-Oct. Vienna: Gebr. Hollinek; 1896. p. 38-48.

32. Mysyrowicz L. Academia and Revolution. Eastern European students in Geneva at the time of Plekhanov and Lenin [in French]. In: Schweizerische Zeitschrift für Geschichte. 1975;25: 514-62.

33. Dienst- und Qualificationstabelle of Krajewska, Dr. Theodora. Archives of Bosnia and Herzegovina.

34. Landesregierung für Bosnien und die Hercegovina (ed): Public Health in Bosnia and Herzegovina 1878-1901 [in German]. Sarajevo: Landesdruckerei, 1903; Table XXV, p. 400-1.

35. Krajewska Th. Annual report of the official female physician MD T. Krajewska in Tuzla for
1897 [in German]. Wiener Klinische Rundschau. 1898;35:566-7, 581-2.

36. Krajewska Th. Annual report of the official female physician MD T. Krajewska in Sarajevo for 1902 [in German]. Wiener Medizinische Wochenschrift. 1903;38:1778-82, 1829-31, 1872-6, 1926-30.

37. Krajewska Th. The experience of a female physician's in Dolnja Tuzla (Bosnia) [in French]. In: Schoenflies R, Morgenstern L et al., editors. Der Internationale Kongress für Frauenwerke und Frauenbestrebungen in Berlin, 10. bis 26. Sept. 1896, Berlin: Hermann Walther; 1897. p. 185-90.

38. Zeissl H. Textbook of syphilis and the related local venereal diseases [in German], vol. II, Erlangen: Enke; 1872.

39. Krajewska Th. Osteomalacia in Bosnia (district of Donja Tuzla) [in German]. Wiener Medizinische Wochenschrift. 1900;50: 1785-1788, 1824-8, 1893 6, 1930-15, 1982-16, 2022-4, 2074-8, 2134-8.

40. Krajewska Th. The tetany of osteomalacic women [in French]. CVIe Congrès international de médicine Budapest, Aout-Septembre 1909 - Compte rendue, p. 418-28.

41. Gelpke L. Osteomalacia in the valley of Ergolz [in German], Basel/Liestal: Druck von Gebr. Lüdi; 1891.

42. Fuchs B. Osteomalacia: Femininity and the "Softening of the Bones" in Central European Medicine (1830-1920). In: Light TP, Mitchinson W, Brooks B, editors. Bodily Subjects: Essays on Gender and Health, 1800-2000. Montreal: McGill Queen's University Press; 2014. p. 123-51.

43. Vrbanić L. Osteomalacia in Croatia [in German]. Centralblatt für Gynäkologie. 1901;25:1; 922-4.

44. Bergmann A. Controlling sexuality. The beginnings of modern birth control [in German]. Hamburg: Rasch \& Röhring Verlag, 1992.

45. Allen AT. Feminism and Motherhood in Western Europe 1890-1970: The Maternal Dilemma. Basingstoke: Palgrave Macmillan, 2005.

46. Januszewska G. On Osteomalacia (including a supplement on tetany) [in German]. Klinisch-therapeutische Wochenschrift. 1910;17(21):503-10.

47. Valverde M. „Racial Poison“. Drink, male vice, and degeneration in first-wave feminism. In: Fletcher IC, Nym Mayhall L, Levine P, editors. Women's Suffrage in the British Empire. Citizenship, Nation, and Race. London/New York: Routledge; 2000. p. 33-50.

48. Richardson A. The Birth of National Hygiene and Efficiency: Women and Eugenics in Britain and America 1865-1915. In: Heilmann A, Beetham M, editors: New Woman Hybridities. Feminity, Feminism and International Consumer Culture. London/New York: Routledge; 2004. p. 240-62. 